UDC 81'42"12/17"

81 '27'12/17"

$811.163 .41 ' 27$

https://doi.org/10.18485/ms_zmskij.2020.68.2.11

\author{
Др Страхиња Р. Степанов
}

\title{
КОЛОКВИЈАЛНО-ЖАРГОНСКА ЛЕКСИКА У РОМАНУ АЛЕКСАНДРА РАШИЋА ОД 13 ДО 18*
}

Предмет истраживања у овом раду је колоквијално-жаргонска лексика у роману Александра Рашића $O g 13$ go 18. Имајући у виду тематско-садржајну основицу, у роману је изразито коришћена омладинска супкултурна дискурсна жаргонизација (остварена не само у дијалошким него и у недијалошким секвенцама). Отуда ће рад садржати следеће делове: у првоме ће бити укратко предочене наративне одлике романа, у другоме ће се класификовати и анализирати колоквијално-жаргонска лексика, у трећем ће се предочити закључци у вези с анализираном лексиком.

Кључне речи: колоквијално-жаргонска лексика, стилизација, „проза у траперицама”, жаргонска (колоквијализирана) проза.

1. Увод. Предмет овога рада је супстандардни, тј. колоквијално-жаргонски ${ }^{1}$ лексички слој у дијалозима протагониста романа $O g 13$ go 18 Александра Рашића, што је наставак претходног истраживања (СтепАнов 2019), у коме је обрађен фонетски/фонолошки поступак жаргонизације (уметничке) разговорне стилизације дискурса ликова у поменутом роману. Запажено је,

* Овај рад представља део истраживања у оквиру пројекта Сйанgарgни срйски језик (178004), који финансира Министарство просвете, науке и технолошког развоја Републике Србије.

${ }^{1}$ Оваква се полусложеничка детерминација користи како би се у анализирани корпус уврстиле и лексеме које су задобиле ширу разговорну рецепцију и продукцију (нпр. кева, ћале, кеи, физичарка, франиускињ $а$, бус, скејй, орйак...) у односу на уско схваћене жаргонске. Уосталом, да граница између колоквијалних и жаргонских лексема никако није јасно повучена, илуструје лепо квалификација речи кева и ћале - тако се у Речнику срйской језика (2007) уз ове лексеме налази квалификатор жарі., док Р. Драгићевић (2018: 191) у својој књизи констатује како је „занимљиво да су се колоквијализми ћале и кева користили, изгледа, и пре Другог светског рата, али је и утицај немачког језика јак, па су потврђене лексеме муйерка и фат̄ер". 
што је било и очекивано, како Рашићев проседе наликује другим књижевницима, његовим претходницима, који узимају за главне јунаке својих литерарних дела малолетне протагонисте, дакле, оне који се налазе у осетљивом, (пре)ломном тинејџерском добу, што је на језичком плану одсликано специфичним вокабуларом (у оквиру омладинског социјалног дијалекта) и, уопште, уочљивим конверзационим модусом, као и лимитираном тематском дисперзивношћу. Стога се - у погледу тематике и, нарочито, језика код А. Рашића - показало оправданим реферирање на „прозу у траперицама” (,jeans прозу”), ${ }^{2}$ коју као литерарно-стилску одредницу 70-их година XX столећа у југословенску књижевну теорију и критику уводи Александар Флакер у својој истоименој књизи (ФлАКЕР $\left.{ }^{3} 1983\right)$, а под чиме означава, у првоме реду, прозу у којој се појављује млади, резигнирани, антисистемски и контракултурни, ,колфилдовски” јунак-приповедач, који конструише и репрезентује, помоћу посебног - (раз)говорног, нестандардног, колоквијално-жаргонског - језика, одређени свет, градећи у њему свој идентитет и предочавајући своја осећања, унутрашња колебања и тескобе, и ставове спрам других особа и феномена који егзистирају (и окружују га) у том свету. Другачије речено, такав пикарски јунак ,изграђује свој осебујни стил на темељу говореног језика градске омладине и оспорава традиционалне и постојеће друштвене и културне структуре" (ФлАкЕР ${ }^{3} 1983:$ 36). ${ }^{3}$ Флакер у својој студији, полазећи од Селинџеровог Ловца у жит̄⿲, кроз бинарне односе предочава одлике тада актуелне југословенске џинс прозе: (а) опонирање света младих и света одраслих, које се, по правилу, реализује (б) кроз супротстављање/сукобљавање два језика (стандард vs. супстандард / дија-

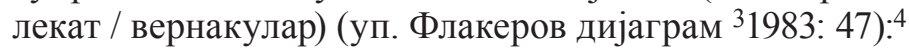

2 У наставку тачке 1 биће делимично преузети (измењени или неизмењени) поједини сегменти из уводног дела поменутог рада (СтЕПАнов 2019).

${ }^{3}$ Сјајно одабрану синтагму „проза у траперицама” Флакер примењује као етикету за ону врсте прозе где млади јунак или његова „клапа” опонира доминантном/наметнутом/ бирократизованом погледу на свет, пре свега, језиком којим се користи, тј. његовом „означитељском разином”. Како Колановић (2014: 130) истиче, Флакер тај отпор сагледава „првенствено у језичном смислу”, али се „у поновљеноме промишљању споменуте концепције отпора из сувремене перспективе ваља нагласити да је језично опонирање неодвојиво од популарнокултурног опонирања”, јер се симболички капитал доминантно црпе из „текстова и пракси популарне културе”. Напослетку, траперице, тј. џинс нису тек обичан одевни предмет него представљају робу с изразитим друштвеним потенцијалом, одн. конотацијом (управо популарнокултурном), због чега су и послужиле Флакеру када је лансирао дати термин у књижевној теорији.

${ }^{4}$ Флакер истиче како аутор тежи својеврсној митологизацији омладинског неконформизма: „налазит ћемо исте или сродне суставе вриједности које млади приповједачи проналазе у сувременој култури и првенствено њезиним масовним медијима: филму, глазби, начину одијевања и књигама. Оспоравајући својим стилом (најчешће националне) традиције и вертикални континуитет њихов, млади приповједачи непрестано наводе имена и појаве сувремености" (ФЛАКЕР 1983: 45). 


\begin{tabular}{|l|l|}
\hline \multicolumn{1}{|c|}{ недорасли } & \multicolumn{1}{|c|}{ одрасли } \\
\hline $\begin{array}{l}\text { ja /лик младића/ } \\
\text { нас двоје /младић и дјевојка/ } \\
\text { ми /ја и моји другови - клапа/ }\end{array}$ & $\begin{array}{l}\text { они /свијет одраслих, структурирани свијет тзв. } \\
\text { трајних вриједности/ } \\
\text { њихове институције /професије, школство, } \\
\text { културне установе, полиција, обитељ/ }\end{array}$ \\
\hline $\begin{array}{l}\text { наша култура /мас-медији, филм, } \\
\text { забавна глазба, наше књиге, наше } \\
\text { одијевање, траперице/ }\end{array}$ & $\begin{array}{l}\text { њихова култура /музеји, галерије, канонизирана } \\
\text { умјетност и књижевност/ }\end{array}$ \\
\hline $\begin{array}{l}\text { наш језик /говорени језик, жаргон, } \\
\text { сланг/ }\end{array}$ & $\begin{array}{l}\text { њихов језик/стандардни језик, језик канонизиране } \\
\text { књижевности, регионални дијалект/ }\end{array}$ \\
\hline
\end{tabular}

У измењеним друштвено-политичким околностима, када је џинс изгубио од свога друштвено-симболичког потенцијала, могућно је да данас „проза у траперицама” делује анахроно или барем неприкладно као вињета за прозни предложак који ће овде бити анализиран, тј. да би примереније било употребити синтагму „жаргонска проза” или нпр. „урбана колоквијал(изира)на проза”, што би одговарало савремености, тј. актуелној ситуацији. Али ако се превасходно има у виду теоријско-методолошко упориште, онда се Флакеров појам (и приступ) намеће барем као полазишна тачка (ако већ не и као путоказ у истраживању). Према томе, управо на трагу поменутих разматрања, која се највише фокусирају на план означавајућег, дакле другачијег језика који конституише идентитет појединца и/ли читаве (омладинске) групе, у овом ће се раду анализирати лексичка разина тог (раз)говорног, „контракултурног” језика који се, ако не експлицитно онда несумњиво имплицитно, супротставља стандардном идиому, тј. језику одраслих. 5 У контексту књижевнотеоријске традиције, Флакерова се дихотомија надовезује на формалистичку (Тињановљеву) разлику двеју функција: синфункције и аутофункције, где синфункција представља узајамни однос неког елемента с осталим елементима у истом систему, а аутофункција пак однос истог елемента према сопственом учешћу у различитим системима. Отуда синфункција има терминативну а аутофункција инхоативну улогу омогућујући међусистемско функционално повезивање. Тако се синфункцијски посматрано конфронтира, у роману неупоредиво доминантнији, колоквијално-жаргонски разговорни стил омладине („ми/наш”) више-мање стандардном говору одраслих (,туђ/њихов”). Тај говор омладине, аутофункцијски

5 Узгредно, о овом феномену могло би се говорити и не нужно из конфликтне перспективе него и са позиција либерализације/демократизације норме, управо како то Р. Драгићевић истиче пишући о неологизмима: „упоредо са интелектуализацијом и терминологизацијом, дешава се један, донекле супротстављени процес, а то је увећање броја лексема у разговорном језику. Свакодневно настају и мењају се лексеме које припадају омладинском жаргону и различитим социолектима. Колоквијализација и жаргонизација лексичког фонда представљају манифестације експресивизације, а према неким ауторима, експресивизација се третира као посебна тенденција у настајању нових речи" (ДрАгићевић 2018: 243). 
сагледан, негативно се вреднује, али се у роману, захваљујући нараторовој перспективи и синфункцијској позицији, ревалоризује, задобијајући друштвено-симболичку конститутивну/конституишућу улогу.

1.1. Да би се овај аспект у Рашићевом делу могао систематски артикулисати, ваљало би рећи нешто о наративним поставкама романа Og 13 go 18 . У појмовима савремене наратологије, која издваја три плана испитивања наративног текста - време, начин и лице (тј. глас) ${ }^{6}$, роман Александра Рашића могао би се, сходно трећем критерију (лицу), дефинисати као хомодијегетско приповедање (приповедач учествује у причи као један од ликова). Og 13 gо 18 пример је, штавише, наративног типа у коме је приповедач не само један од јунака приче него њен главни јунак (тзв. аутодијегетски наратор). Ово је релевантно због супстандардне језичке супстанце: како у виду колоквијално-жаргонске лексике тако и у бројним примерима гласовних модификација и мутација речи, тј. фонетских метаплазми (в. о томе у СтеПАнов 2019). Шмид (Sснмід 2010: 118) у својој Нараӣолоїuји подсећа како је још Платон разликовао два базична модела представљања говора - миметички (у драми) и дијегетски (својствен поетским дитирамбима) - док је наративни (тзв. епски) текст одликовало комбиновање ова два основна начина говорне репрезентације. И у Рашићевом се роману, дакако, могу разлучити дијалошки и недијалошки сегменти, што значи да су, на једној страни, они делови који миметичко-драмски представљају разговоре у којима учествује главни јунак, а на другој, „циркумстанцијални” сегменти, тј. они који описују спољашње и/или унутрашње околности у којима се одвија радња (и промишљање јунака романа) и који окружују и „меандрирају" кроз дијалошке сегменте. Отуда је - на плану језичког/стилизацијског истраживања - оправдано бавити се овим двама сегментима оделито (као што, свакако, би било оправдано и скупно представљати језичка и стилска обележја ових делова, ${ }^{7}$ већ и према спољашњем, семиотичком оквиру [роман као целина] али и захваљујући унутрашњем/кохезивном, језичком механизму - жаргону, који прожима и један и други сегмент, значи и недијалошку деоницу и деонице ликова). Условљени примарним интересом за говорну карактеризацију ликова, тј. колоквијално-жаргонску лексику, у фокусу овог

\footnotetext{
6 Женет истиче како се наративни тект испитује на три плана - на плану времена, начина и лица. Марчетић каже (2003: 65): „Термином глас (voix) Женет означава један посебан аспект наративног текста: онај који се односи на функције субјекта исказивања, односно приповедача. (...) За разлику од традиционалног термина лице, Женетов глас не односи се само на граматичко лице приповедања (приповедање у првом или приповедање у трећем лицу), већ на сва питања која се тичу односа између субјекта исказивања (приповедача) и самог исказа (приповедног текста)". У складу с овим критеријем Женет разликује хетеродијегетско приповедање (приповедач одсутан из приче коју приповеда) и хомодијегетско приповедање (приповедач учествује у причи као један од ликова).

${ }^{7}$ У литератури се нпр. говори о једногласној (дијалошкој) и двогласној (дијалошко-монолошкој) стилизацији (уп. Тошовић 2002: 251).
} 
истраживања биће само дијалошки сегменти, прецизније речено, циљ је рада детаљније изложити и описати супстандардни лексички слој говора протагониста романа, уз обазривост која је нужна, јер су најпосле и говор ликова и говор наратора „уједињени наратором плетући тако наративни текст. (...) Аутономија говора ликова је варљива; у стварности, говорни ентитет у дискурсу ликова је и даље песник, тачније наратор" (SCHMID 2010: 118), па управо стога што је наратор творац наративног текста он је „у могућности модификовати и говор ликова" (Ibid.).

1.2. Главни протагонист романа $O g 13$ go 18 остаје до краја неименован (на последњим страницама романа сазнајемо тек његов надимак). Типолошки је већ речено каква је његова наративна позиција, а када је реч о тематско-садржајним одликама романа, може се истаћи следеће: аутодијегетски јунак је у осетљивим, тинејџерским годинама (управо као у наслову) - читалац прати шта му се [том јунаку] дешава и кроз шта пролази од 13. до 18. године живота. За тај транзиторни адолесцентски период, рекло би се, уобичајени идентитетски ломови: преиспитивања, покушаји социјализације с различитим (маргиналним и, у каснијој фази, с оне стране закона) младићким груп(иц)ама, тражење свога $j a$ и његово преобликовање/акомодирање према понашању (и „светоназору”) „екипе из кварта”, прве љубави и разочарања, неузвраћена осећања, сексуална искуства, склизнуће у (полу)криминални миље, уз почетак конзумирања прво тзв. лакших а потом и тежих опијата и опиоида, подбачај а затим и тотално „потонуће” у школовању (што се завршава исписивањем из редовне и уписивањем на ванредну наставу) итд. - предмет су литерарне обраде Александра Рашића. Заправо приповест која слика суморну судбину једне изгубљене генерације, у teenгодинама, с краја осамдесетих и почетка деведесетих година XX века, чији ce grande finale мора окончати - јер уистину нема никакве наде (са̄м A. Рашић ће горко узвикнути: Желим у себи вище Неба!) - само на дну, ситуирана је у време потпуне друштвене дегенерације и аномије, када се вредносни систем, дотад помоћу репресивних и идеолошких државних апарата негован, показује као сасвим изнутра труо и црвоточан, кулминирајући распадом државе и крвавим пиром на њеном простору. Тако се индивидуални и колективни ниво деструкције и распада преплићу и сједињују кроз причу о одрастању главнога протагонисте, где се заправо индивидуална приповест гл. јунака може схватити као метафора колективног (социјалног) расапа и декаденције.

1.3. Ради што аутентичнијег приказа комуникативног догађаја и конверзационог стила учесника, као и карактеризације самих ликова аутор се користи, наравно стилизованим, ${ }^{8}$ (нестандардним) разговорним функцио-

${ }^{8}$ Као што је познато стилизација је метакреативни поступак, којем је својствено „опонашање језичних средстава карактеристичних за неки тип језичне реализације у сврху остваривања одређене умјетничке функције” (КАтнић БАКАРшић 2007: 113). Тошовић (2002: 
налним стилом. Јер, разговорном стилу јесте својствен „незванични, неусиљени, спонтани (...) дијалошки начин изражавања, за који не постоје могућности веће припреме, који се реализује у директном (...) контакту, у близини (...) и у коме саговорници истовремено или сукцесивно шаљу и примају поруке“" (Тошовић 2002: 381), ${ }^{9}$ као и комплексност (како је разговор резултат

384) напомиње да разговорни функционални стил „долази као природни ('сирови') и као стилизовани (рефлектовани, одсликани, обрађени) начин изражавања", где се онај први везује за облик независног усменог комуницирања, а други као сегмент других стилова књижевног, публицистичког, административног, научно-популарног. Управо овом другом - рефлектованом - разговорном стилу посвећује се пажња у раду. Само узгредно, у вези са ширим сагледавањем овде назначене проблематике, требало би истаћи да данас у лингвистици постоје следећа мишљења: говорећи о филмским дијалозима, и филму (сценарију) у начелу као корпусном предлошку, нпр. Шеглоф (SCHEGLOFF 1988) или Емисон (EMmISON 1993) указују на то да језик филмског сценарија није спонтан, да је вештачки (тј. није емпиријски - што је ваљда очито) и стога упитан у погледу легитимности за конверзационо истраживање, док на другој страни Боксерова (BOXER 2002: 18) налази да су филмски дијалози „најприближнији могући пандан спонтаном понашању људи у свакодневној говорној интеракцији", и свакако валидан материјал за изучавање.

9 Тошовић (2002: 382) инсистира на томе да се термин „разговорни стил” разликује од од других назива за усмене форме језика, какви су „говор”, „усмени говор”, „,вакодневни говор”, „живи говор”, „усмени језик”, „разговорни језик”, „колоквијални језик/говор”, „говорни језик”, „усмени/говорни начин изражавања”, „говорна комуникација”, „стил изражавања у говору/говорној комуникацији”, , супстандард”, „супстандардни језички израз”. Оправдање за то он налази у томе (а) што разговорни стил означава једну од пет врста функционалностилске диференцијације и (б) што се веже за стилистику. У стручној се литератури оно што код Тошовић обухвата садржај појма „разговорни стил” назива и „разговорни језик” (уп. САвић, Половина 1989). Јер, интеракцију, спонтаност, неусиљеност, незваничност, аутоматизованост (стереотипност, формулаичност, клишеизираност), егзофорички утицај узимају и Тошовић (2002) али и Савић/Половина (1989) као значајке разговорног стила, односно разговорног језика. Ипак, овде је битно истаћи, посебно кад је реч о терминолошкој (не)јасноћи, да Тошовић користи и појам „разговорни језик” (=усмени говор) дистингвирајући га од „разговорног стила” и закључује како се под разговорним језиком подразумева „било који облик усменог изражавања” (Тошовић 2002: 382) покривајући говорне форме осталих Ф-стилова (изузев разговорног Ф-стила). Мало другачијег је става Стана Ристић (2006: 54, 55), која ослањајући се на Лубашева (и Дел Хајмзова) разматрања, подупире закључак, заснован на критерију распрострањености (масовности употребе), да је разговорни језик врста језика а не Ф-стил, те се тако разликују, на једној

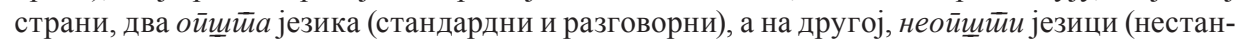
дардни, неразговорни, жаргонски итд.). /В. и наредну подбелешку./ Каткада се употребљава и ортографска варијанта „(раз)говорни језик”- што је последица жеље да се истакне једна црта - (дијалошка) усменост, оралност - значи да је реч о говореном медијуму. Д. Кликовац (2008: 159) примећује како „од свих манифестација језика у говору, постоји једна која је типична (примарна и у онтогенези и у филогенези, а и најчешћа у човековом животу): у питању је разговор (дијалог или, ређе, полилог), који се остварује у неформалним ситуацијама, спонтан је, неприпремљен и води се на теме из свакидашњег живота. Тако би говорни и разговорни језик били типични представници говореног / усменог језика. Управо зато је та два појма понекад тешко теоријски раздвојити, а из истог разлога се у лаичком 
учешћа више саговорника), динамичност (створена у самом моменту разговора), ситуациона усидреност (стога је под утицајем егзофоричких фактора), разноврсност (САвић, Половина 1989: 2), те „велика варијабилност” (ibid., 3). Будући да је „природна сфера овога стила свакодневно комуницирање, приватни разговор, неусиљено ћаскање” (Тошовић 2002: 381), његова је употреба посве логична и оправдана у дијалошким секвенцама романа. Вокабулар главног јунака као и његових другова (из школе и из кварта) почива у значајној мери на разговорно-жаргонској ${ }^{10}$ лексици, сасвим у складу с оним како се они самоодређују - као „деца с улице”, и то периферије (па макар то био и град Земун), што напосе, по Тошовићу (2002: 393), и јесте одлика разговорног Ф-стила, где „долази до великог мијешања двају комплекса - стандарда и супстандарда". ${ }^{11}$ Стога би најпрецизније било рећи како читалац романа $O g 13$ go 18 у дијалозима сусреће „жаргонско-колоквијални (раз)говорни идиом омладинског социолекта” или „омладински (урбани/градски) вернакулар”, чиме би биле сигнализиране две кључне особине стилизованог језика младих у роману: прво, мноштво жаргонизама/колоквијализама, који ипак највидљивије обележавају тај говор; и друго, да се односи на тзв. обични говор којим се служи млађа популација у свакодневним ситуацијама. ${ }^{12}$

2. АнАлизА и дискусијА. У уводном је делу истакнуто - што је очито и из наслова - да је у фокусу ове приповести одрастање главног јунака у адолесценцији. У учењима психолога ово се животно доба одређује као прелазан, транзицијски период, јер се чини социо-психолошки значајан одступ у односу на претходеће, предадолесцентско доба, којем је својствена потпуна зависност спрам родитеља/старатеља, док на другој страни још није

осећању и не раздвајају”. На то двојство (спонтаност/неприпремљеност и усмени медиј) указује се, дакле, коришћеним ортографским маниром - „(раз)говорни”.

10 Овде термин «разговорни»/«колоквијални» у знатној мери одговара ономе о чему пише Стана Ристић (2006: 55-56) у својој књизи именујући то «разговорна лексика». Она истиче како се „особеност разговорног језика испољава, поред осталог, и у лексици”, па се на основу неких специфичности „одређене лексичке јединице издвајају у посебан слој «разговорне лексике»”, (...) те се „категорија разговорне лексике јавља у вези са разговорним језиком, али не обухвата целокупан лексички инвентар овог језичког система (...)”. Ти критерији специфичности би били: употреба и могућност избора.

11 Због тога се разговорни стил пре посматра као градуелни а не строго омеђени идиом: који се на једном крају у највећем подудара с нормом, док на другом крају у знатној мери одступа и опире се тој норми, или, другим речима, „нормативност РФС је релативна и варијабилна особина" (Тошовит 2002: 393).

12 Уп. Бугарски (1996: 172): Градски језик се „односи, пре свега, на обични говор којим се градско становништво служи у обављању свакодневних потреба и послова друштвеног саобраћаја, затим на говорни и писани језик који се примењује у ситуацијама које захтевају приближавање стандардној књижевнојезичкој норми, и на крају, на оне разнолике елементе који утичу на стварање и престварање обају ових главних токова језичке активности градског човека (...)". 
остварена (потпуна) независност што долази у каснијем животном добу. Дакле, током адолесценције млади уче, усвајају и развијају нове социјалне улоге уз полако ослобађање првобитних „окова”, тј. теже ка што већој аутономији личности и независности. Такве промене прате два антагонистичка процеса: слабљење (покушај минимализовања) родитељског утицаја и интензификација утицаја пријатеља и вршњака, одн. генерацијских другова. Хијатус спрам претходног периода може се очитовати на различите начине: у понашању; изгледу, држању и облачању; и, овде релевантно, комуницирању. У социолингвистичким радовима већ је примећено како је ,адолесценција можда најистраживанија животна фаза. Сматра се да вршњачке групе врше велики нормативни притисак у овој фази живота, а то је комбиновано са смањеном осетљивошћу на утицај друштвених норми које представљају институције одраслог и вањског света. Можда је као резултат тога широко распрострањено мишљење да је адолесценција жаришни период језичке иновачије и иромене" (Llamas 2007: 71).

Ова ауторка (ibid.) подсећа и на речи Екерта (1998), према коме „адолесценти доминирају у односу на сва остала животна доба када је реч о гласовним модификацијама и уопште употреби вернакуларних варијанти, што се приписује ангажману адолесцената у изградњи идентитета који је у супротности - или барем независан - од њихових старијих". Према томе, циљ такве језичке перформансе је колико дистанцирање од језика одраслих толико и потреба за генерацијском социјализацијом, тј. жељом да буду прихваћени од својих вршњака. ${ }^{13}$ Социолекти управо одсликавају „разлике између појединих друштвених целина у оквирима говорне заједнице, међу друштвеним слојевима, структурама, групама" (РАдовАновић 2003: 175), при чему је свакако једно од најупадљивијих обележја језика адолесцената колоквијално-жаргонска лексика, чијом употребом се намерно настоји истаћи посебност, различитост.

Радовановић (2003: 176) истиче жаргон као „карактеристичан пример социјално мотивисаног језичког раслојавања, тј. издвајања друштвених

13 Зато Р. Бугарски (2006: 13) наглашава два основна - лингвистички и социопсихолошки - аспекта жаргона: „са социопсихолошке стране, суштина жаргона и темељни разлог његовог постојања представља потреба чланова неке друштвене групе да и нарочитим вербалним средствима афирмишу свој идентитет и потврде своју припадност групи", док лингвистичи посматрано, жаргон подразумева „специфичне лексичке и фразеолошке јединице (...)". Говорећи даље о омладинском типу жаргона, као и супкултурном, Бугарски (2006: 14) скреће пажњу да они обилују маштовитим и живописним креацијама, а речи често излазе из оквира појединих група „улазећи у шири оптицај као нека врста општег жаргона”. Дакле, тзв. омладински жаргон се може наћи у свакодневној употреби и у говору старијих, а када се устали, жаргон може преко разговорног језика постепено да уђе и у стандардни језик. Бугарски (2006) наводи следеће карактеристике жаргона: лексичка продуктивност, иновативност, граматичка флексибилност, метафоричност, поигравање звуком и значењем чиме настаје нешто неочекивано али врло ефектно. 
група у овом погледу”, док Бугарски (2006: 12) одређује жаргон као „сваки неформални и претежно говорни варијетет неког језика који служи за идентификацију и комуникацију унутар неке друштвено одређене групе - по професији, социјалном статусу, узрасту и слично - чије чланове повезује заједнички интерес или начин живота", које одликује употреба специфичних језичких средстава, нарочито лексичких и фразеолошких (ibid.), чинећи га слабо/слабије разумљивим другим говорницима истог језика који га пак негативно вреднују у односу на књижевни језик (БугАРски 2006: 12). Дакле, одређене социјалне групе користе жаргон како би се (и) језички дистанцирале од остатка друштва, инаугуришући га у врсту симболичког маркера. ${ }^{14}$

2.1. Конверзација је, са читавим инвентаром, селекцијом и продукцијом коришћених језичких средстава, битна за изражавање и регулисање различитих димензија друштвеног идентитета као што су социокултурна, генерацијска и групна припадност. Како се језичким деловањем дефинишу, потврђују или оспоравају међуљудски односи, путем језика појединац верификује свој статус унутар друштвене групе (припадници неке друштвене групе у комуникацији користе иста или слична језичка средства).

2.2. У наредном сегменту биће приказани примери употребе колоквијално-жаргонске лексике у говору омладине у роману $O g 13$ go 18. Лексеме у говору младих највише се везују за домен номинације (других особа) и конзумације/уживања у дроги (и пићу), уз наравно најфреквентнију опсцену лексику. Анализа је извршена класификовањем лексема у тематске категорије. ${ }^{15}$

* Жаргонизми и колоквијализими за номинацију

а) особа у родбинском односу

- Јел йе йо кева учила који слаgолеg gа јеgещ? Хахахахаха... (10) - Фора је сакуйищ мало киниее и оняа оgещ коg матиорой и куйищ јачи буздован, бољи оклой, вище енеріије....(10) А моја кева је навећа оg свих. (15) - Како можещ йако gа ирричащ о рођеној кеви? (15) - Како мислищ,

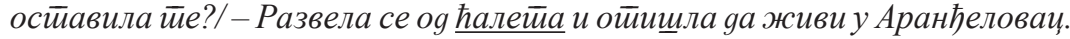
(15) Ший иии је с ћалейом? (15) - Лейи је живео са кевом, ћалетиом и

\footnotetext{
14 Бугарски (2006) наводи да су жаргони криминогених супкултура, тј. супкултура које су на удару закона, намерно неразумљиви изван те групе у циљу заштите од „провале” спољног света.

15 Паскал Гете (GAItET 1992), испитујући субверзивни потенцијал употребе нестандардног стила у литератури, уз нужно ослањање на Бахтинове идеје (о језичком раслојавању у роману), пише у својој Политиичкој стиилистииции о тзв. маркерима супстандарда/ вернакулара [popular markers] на трима нивоима: фонетском, лексичком и синтаксичком. Када је реч о ономе чиме се бави и овај рад, дакле лексичким обележјима, ауторка сматра да се треба поставити питање: колико су те речи далеко од нормативног (прописаног) вокабулара, у којој су мери (већој или мањој) колоквијализиране, за које мотиве/теме се везују итд. Док прво питање, у нашој анализи, остављамо по страни, а друго „решавамо” не разликујући (строго) колоквијалну од жаргонске лексике, треће питање се разматра кроз класификацију лексике према тематској припадности.
} 
млађим буразером у йреуређеном вайону, неі̆gе йре Сајма. (24) - Живео је неколико зіраgа о м моје куће, са кевом куварицом у Галениии и ивецом

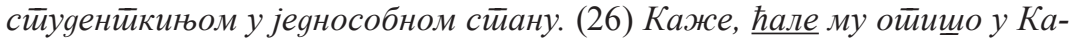

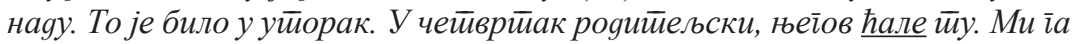
йитиамо, йа јел йи ћале није у Канаgи... (33)

б) мушких особа у другарском / пријатељском / колегијалном и непријатељском / неколегијалном односу и других

(...) gа бих избеїао малӣретиирање неког оg локалних блејача. (7)

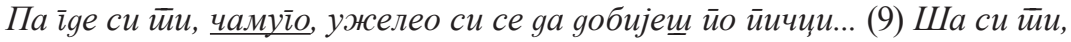
gериее?! (10) Ало клињо, йази како се йонащами! (11) Остиавила ме збоі не-

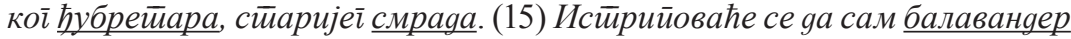
и биће іа блам оg мене. (16) Ajgе саg найоље, смраяе майори! (18) Који си тии болия, коњино! (25) И иитиа, яувао си ко клошар на улиичи!? (27) По-

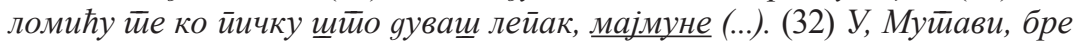

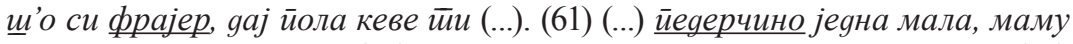

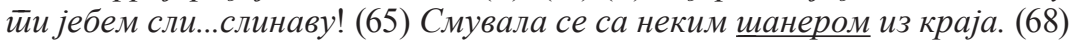

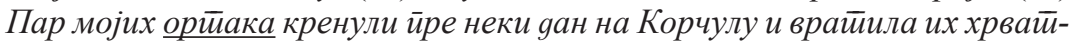
ска мурија (...) иретиресали их као кримосе (...). (75) Остиао сам с она gва билмеза. (78) Иуемо у КСТ, свирају ови менитоли, оћетее с нама? (88) И он је будала, само шитоо је он вище кримос и ито... (89) (...) јао шитиа стие ми ураяили, иичке јеgне (...). (107) Ияем кући, йреба gа се чујем са орйаком. (109) Е, јак си ми тит фрајер. (122) -Ајgе Дебели, шит̄о си сиса (...). (155)

в) женских особа

Али шитиа ако оялуче gа зайале на кеј gа јуре неке рибе. (7) - Јесу неке рибе с вама? - Па gа, наравно, увек су т̄у неке рибиче. (12) Kag сам

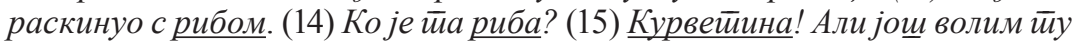
кучку. Све жене су курве. (15) Оняа їа ја и йа йичка тиражимо йо іраяу (...). (15) Живи с неком Рускиьом, жешће млаgом рибом. (15) Шйа је с йобом, имаш ли тии неку рибу? (15) Маgа има яобрих риба, али не ярже gо себе. (33) Франиускиња је ойасна йичка, йлавуща. (36) Ку..курвейина нека, а? (36) Ма јок, имам две gобре йичке у разреgу, али нишйа нисам ураяио. (68) Лейи је оg gебеле баба-сере йазарио яве йакле Сарајевске Дрине. (70) Кайирам gа има іомила клинки заљубљених у тиебе. (84) (...)

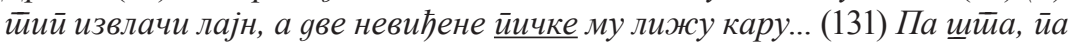
и ја gа сам неки кримос само бих блејао йо хоиелима, карао курве, раяио кокс (...). (135) -Ойасно gуйе! (156)

Уочава се да омладина, у роману, у конверзацији не употребљава друге номинационе изразе за родитеље осим колоквијалних кева и ћале, док мајка,

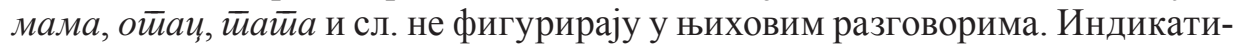
ван је у том погледу разговор који главни јунак води, прво, с тетком свог друга, која га подучава математику, одн. „матиш”, а потом и (преко телефона) са својом мајком (тачније, он се претвара да води тај дијалог с мајком како би се ослободио навалентне тетке):

-Сйварно морам, мама ми је рекла gа обавезно дођем раније. (...) Хало, мама, ја сам (...). Али мама, сииварно учимо, не иірамо иірице... (74) 
Дакле, једино у овој ситуацији главни протагониста корист реч мама, у свим осталим он и његово друштво употребљавају колоквијализам кева. Још упадљивија је употреба речи риба за девојке. Девојка као лексема у овом социолекту практично не постоји, а поред рибе још се јављају и пејоративне кучка и курва/курветиина, док је с позитивном конотацијом - у датом

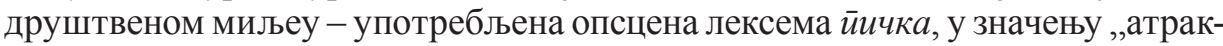
тивна/згодна девојка". Уочљиво је да, кад је реч о номинацијама женских особа, доминира негативно интонирана експресивност лексемских јединица. Слична је ситуација и с номинацијом мушких особа, где се региструју врло често изразито увредљиве лексеме (смрая, Ђубрешиар, коњина, болия и сл.), а изузетак (од ових негативно конотораних лексема) у овој групи би представљале само две речи: фрајер и орйак.

* Жаргонизми и колоквијализими из области школства

Франиускиња је ойасна йичка, йлавущи. (36) Поново смо слущиали

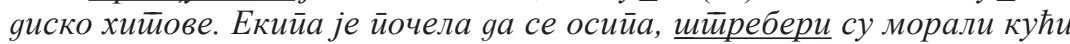
о ммах йосле йоноћи. (51) Слеgећи час био је майиш. (56) Имао је gва кеиа која је морао gа йойрави, йа није смео найоље. (59) Јао, морам gа йоиравим јеgнои кеиа. Замисли, физичарка ми яа кеиа йреg сам крај йоgине (...). (71) Био је најстиарији йрофа у шкколи, делило їа је іооину gана gо йензије и није їа вище било бриїа ни за щйй. (120)

Од колоквијализама везаних за школу већина би се такође могла сврстати и у претходну групу јер служе за номинацију било наставника појединих предмета (франиускиња, физичарка) било одличних ученика (쓰ебер). Овде су класификовани јер припадају не толико бројној групи лексема у вези са школским амбијентом. Преостале лексеме су такође одавно потврђе-

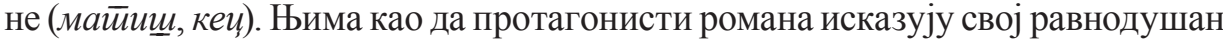
(пре него негативан) став према школи, наставницима и оним вршњацима који немају исти поглед на свет или школске обавезе као они (нпр. употребом речи ийиребер главни јунак као да се подсмева вршњацима који се труде да буду добри у школи и који се, за разлику од њега, нису одали пороцима). Уз то, многи би се примери најпре могли тумачити као случајеви језичке економије, где се дуже речи скраћују (йрофесор $\rightarrow \bar{u} р о ф a)$ или синтагме универбизују (ирофесорка физике $\rightarrow$ физичарка).

* Жаргонизми и колоквијализми везани за дрогу, цигаре или пиће и уживање у њима

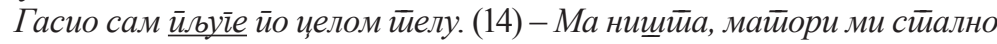
иррави циркус. Пре неки дан смо Лейи и ја дували йакле овgе каgје он уйао... / - Шйа сйе раяили? / - Пиркали. Никау ниси иииркао? - Нисам. / - Мо-

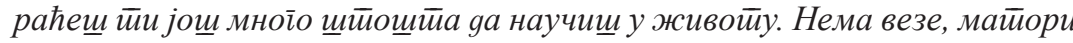
је йолудео кая нас је вияео, хиеео gа зове мурију. У сиивари, највище їа је изнервирало щйо је Лейи йойщщо gаску кая је био у клоњи. Такав је он, майори баксуз, умире већ gваес' іодина. (19) И ко све ииирка? / - Сви, цела екийа сем Муйавоі̄. Он се нещйо истирийовао gа неће gа йроба. (19) 
Сйално се gрао кая иррича. Дувао је лейак. Иуемо gа вамоgу йакле, не можеш са нама. (21) Иуемо gа вамоду иакле, не можеш с нама. - А како муйави може кая и он не qува? (21) Пиркаће нас чейворо, йреба нам gванесии сексона, рекао је Ћойави. - Пиркаћу и ја, оћу gа ирробам. (21) Ево ја gувам већ gве іо оине и није ми нищйап! (22) А како знам gа сам йодувао?

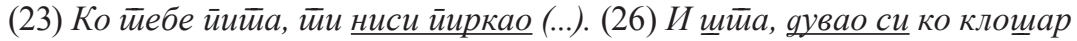
на улищи?! (27) Гgе ћещи бре, йу је он, иимрка йа нас не чује. (29) Био сам ја коg Маре, али нисам gувао, само сам сеgео... Ма немој! Они gувају, йи

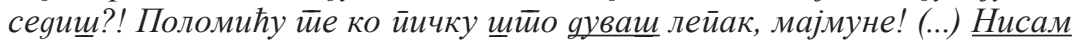

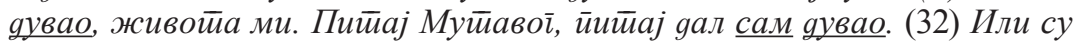

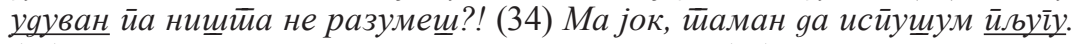
(35) Можgа ако се уйије, може gа буде свашйа... (36) Био је у ко зна којим халуиама. (67) Глеgао сам са ситране и налазио сам се у ексйази. (89) Њеі̄ов орйак са Церака и он циркали су домаћу рачу и већ су били йойри-

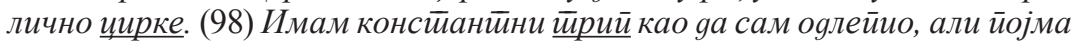

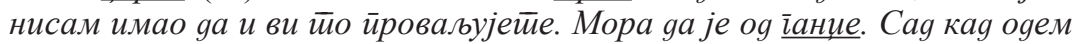

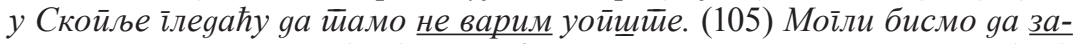
вијемо још јеяну иору. (106) Уваљаћу іа било ком ианкију на gемију. (110)

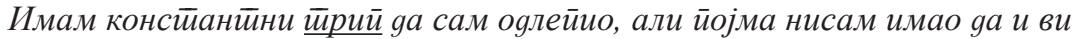

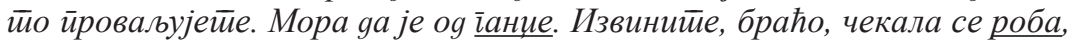
нисам моїао раније. (110) -Какав је йаjgo? (110) -Шйа какав је йајgo? (...)

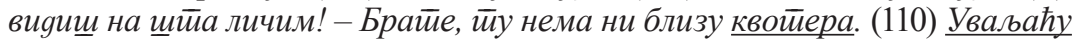
іа било ком ианкију на gемији. (110) Дой је био ирилично лощи, и у мени се мешао осећај мучнине и завоgљиве омамљеностии. (111) Није ми било йрви йуй gа цимрчем, осећај ми је био йознай, али јоши увек нов. (111) Бра-

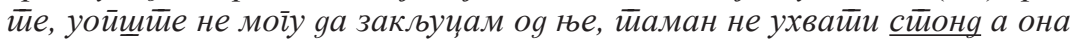
йочне gа меље. (113) Гgе тии сйоји варене? - Пали брайе! Сйавам. - Само

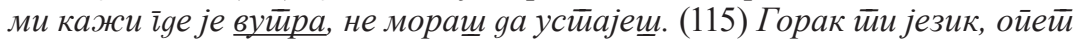
си се нечим ураяио! (122) Има све gа иоойрощищ на ㅎgpy. (123) Ионако

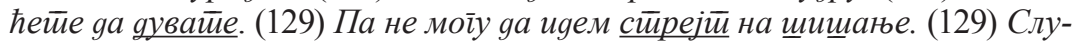
йај, зйуйам ја ово, йа йалимо (...). (129) Па нищйа, ај неїgе gа сроламо,

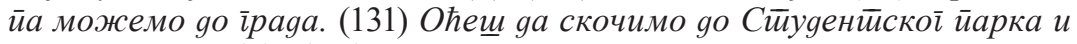

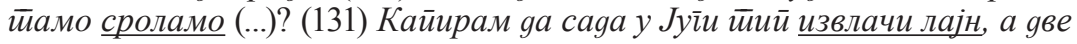
невиђене иичке му лижу кару... (131) Па шйа а, и ја gа сам неки кримос само бих блејао йо хойелима, карао курве, раqио кокс (...). (131) - А био сам у фазону gа зйуйам неке йродончиће (...). (134) -Не знам за вас, али ја вище не мог̆у gа варим. (134) Они су йрионули на йиво, а ја на коцу. (136) (...) gа бих морао gа ояем коg йсихијатира и о омах ирекинем са уgрирањем. (139) Имащи ли неки qонйро вищка? (141) Позови Комщију, чујем gа је йун циче. (141) Ђонови су ми йребали само gа би се gораяио и gа іа суйра

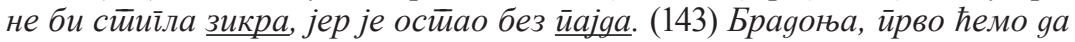
сроламо йвоје варење, gа бамйро йо о чему иричаш. Oћу gа оверим тио есия варење, ајgе брайе, смойај оума цору. (146) Да брайе (...), није класична овера, изілеgа gа му је неко намерно увалио ойров. (150) Найерали

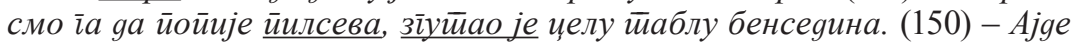
Дебели, иитоо си сиса, извуци јоми који лајн gа се ураяим ко човек. (...) - Ма у реgу је тйо, али само јом мали лајн, gа не буgем на йола. (155) Зикра ми је, нећу закунитайи. (157) Обуку се и нашмрчу ко коњи. (158) - Јеси у фазону gа се исиимамо мало gо qуjіре? (161) 
Жаргонизми и колоквијализми из овог поља убедљиво су најбројнији (уз оне који припадају опсценом вокабулару) у дијалозима у роману. Употре-

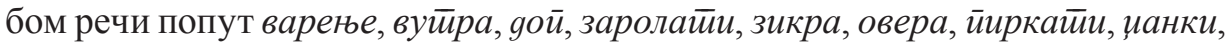

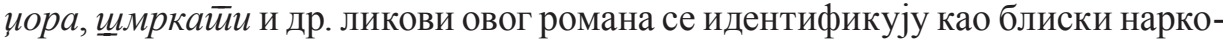
манском миљеу, а познато је како наркоманима жаргон представља неку врсту арканског вербалног заштитног знака по коме се разликују од осталих.

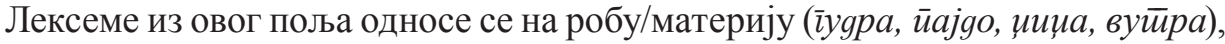

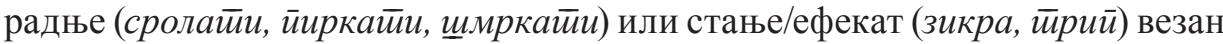
за наркотике. Доминација лексема из овог поља говори о свакодневици јунака романа, која се најчешће своди на покушаје да се дође до неког опијата/ опиода ради конзумације, јер како главни јунак каже девојци, која упорно одбија да узме тродоне: -Ајgее, йоииј само йар комаяа gа ми йравищ ярущииво.

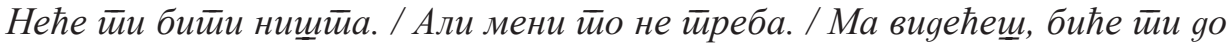
јаја, ајgе збой мене, молим йе.

Поред појединачних лексема, региструју се и колокације: извући лајн, завијатии иору, раяитии кокс.

Захваљујући бројности примера у овој групи могу се уочити различити механизми настанка жаргонизама: нпр. жаргонска семантизација постојећих стандардних речи (варийи - „пушити траву, марихуану”), морфо-фонетски адаптирана позајмљеница (лајна - ,линија праха наркотика који се у том облику ушмркава”; $\bar{u} р и \bar{u}$ - „доживљавање визуелних и звучних халуцинација”), пермутација слогова и гласова (зикра - „криза”; іуgра - „дрога”; вамоgу - „дувамо”) итд.

Жаргонизми и колоквијализими везани за одређене превозна средства и гориво

Већ неколико месеции йу сам чекао бус каg йалим у іраg, gа бих

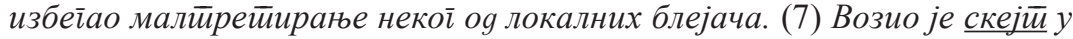
четиири дисиийлине. (7) Немаш вище дневних йейнаја. (19) Он сам у злайари ко у самойослузи. Накуйи се, уђе у ауйо. Неће gа уйали. Осйо без чорбе. (52) Целе ирромле іояине йройушйао сам и йо gесей йейнаја са Зелеьака каg сам се враћао из іраgа, само gа је вияим како излази из неке йеgес'ӣројке. (68)

* Жаргонизми и колоквијализими за означавање ентеријера и екстеријера (микротопонимија)

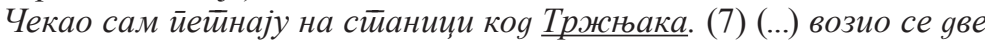
сиианице иррема Калишу. (7) Сйиїао сам на Зеленаку ионоћ и који минуй. (19) (...) и gок смо иролазили йореg Oбgаје, обgанищйа које је било коg наше основне (...). (33) Иgемо у Мијуча (...) (21). Сјурили смо се йарком gо

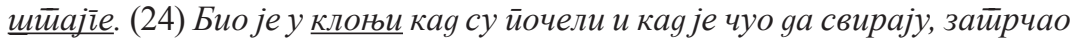
се, йойео се на бину и ирви скочио на стиеји. (...) После су се у бекстиејиу уйознали с беняом. (89) Ма нема щанси, морам саg gа сеgим їајби. (119)

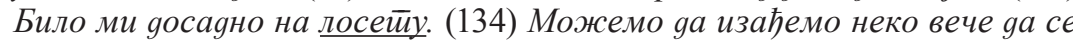
ирометиамо, у неки фићка (...). (155) Ево ме їајби, ілееяам йе-ве, безвезе. (160) - Да се увалимо у неки фићка (...). (161) 
Жаргонизми и колоквијализими везани за новчана средства

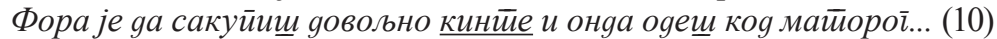

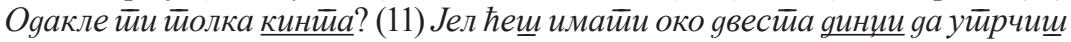
за виьак, мислили смо gа свако gа неку кинйу? (99) Можgа си у фазону

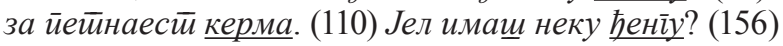

Жаргонизми и колоквијализми из претходна три поља, слично онима везаним за школство, најпре се могу објаснити језичком економијом: уочава

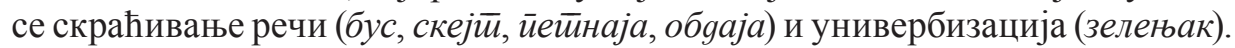
Наравно, приметно је и шатровачко поигравање пермутирањем слогова

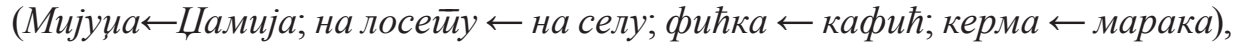
као и употреба позајмљеница (Ђенї $)$.

Ж Жаргонизми и колоквијализими везани за исказивање оцене, става, осећања

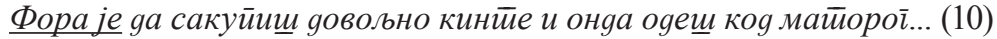
Било ме је блам gа ирризнам gа нисам вияео йако лейендарну иіру (...). (10)

* Жаргонизми и колоквијализими везани за понашање и људске активности Али шита ако оgлуче gа зайале на Кеј gа јуре неке рибе? (7) Браgоюа, саg ће јеgно йейлање... (9) Имаш среће gа сам йо ја, неко би йе већ

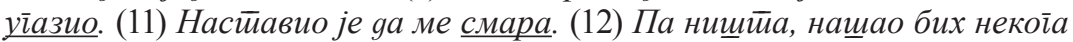
gа блеји у насељу, йа би блејали зајеgно. (12) Блејим на комйу. (17) Да ли сам ја нормалан?! Ко зна їgе се смуиам! (20) Палимо неїgе, вияимо се суйра, буяи у Руйи. (20) А мени звучи слейачки gа йо цеео gан блејим у насељу. (27) Не, брайе, шитековали смо се, иррво у некој цамији... (27) Добро, ај сая йали! (28) Провалийе, Кокощка се лаяно йоййисао као Рири... (65) Немам їgе gа је сйарйујем. (68) Суйра, каg сам је вияео на йлажи, у куйаћем косиииму йойиууно сам оялейио. (69) Гойиви он йебе, реко ми је.

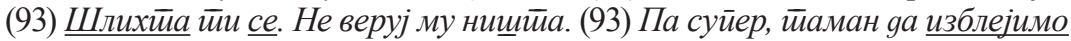
на йрибинама. (133) Па брайе, јел можеш gа ми уйрчищ йар комаgа? (134) Знаш, брайе, овgе је увек било местио за набаgање. Каg се закаче gва насеља, закажу фајй овgе. (...) -Ти си се као набаяао? (142) Наравно,

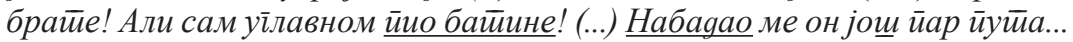
- Јеси т̄и набаgао некой? (143) Можемо gа gамойле неки филм. (149)

На основу бројности примера може се закључити како је и поље везано за понашање и људске активности битно у омладинском социолекту, те су колоквијално-жаргонске лексеме фреквентније у односу на друга поља (осим оног везаног за дрогу и конзумирање таквих супстанци). Те лексеме се односе на конкретне активности које јунаци изводе (или то планирају), дакле на нешто што сами чине, у ситуацијама у којима се свакодневно налазе, па не чуди њихова бројност. Од ексцерпираних лексичких јединица истичу се оне везане за доколицу, одн. потпуно одсуство било какве (физич-

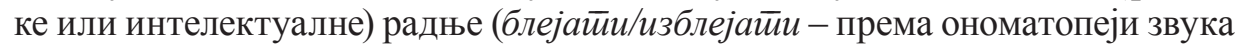

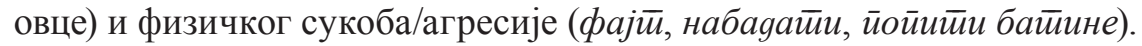


* Жаргонизми и колоквијализми за номиновање различитих предмета, апарата

Ма немој, а їgе си је иірао?-На комйу... (10) Био је блаі̄о менйално рет̄аряиран и носио је цвикере с оіромном яиойиријом. (134)

* Жаргонизми и колоквијализими везани за квалификацију предмета или нечијег стања

Знао сам gа се раяило о некој луяој аркаяној аванйури. (10) Нисам био луg gа му тио иризнам. (16) Музика је била ший. (79) Ма јок, мислиши на

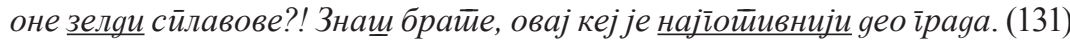

У последњим двема групама налазе се малобројни примери који се односе на предмете, уређаје или служе за квалификацију: колоквијализми и жаргонизми су настали као последица гласовне редукције (комй $\leftarrow к о м \overline{u j y-~}$ $\bar{u} е р)$ или пермутовања слогова (зелgи $\leftarrow$ gизел), померања значења (лyg).

* Непристојна, срамотна (опсцена) лексика

Опсцена лексика се односи на номинацију неких делова тела/органа, као и радњи повезаних са сексуалним и/или екскреционим пробавним активностима (уп. ШипкА 1999: 15). Марина Вицановић (2017: 173) наводи да је „нарочито код Срба, и на нашим просторима, коришћење опсцене лексике и лингвистички, и психолошки, и социолошки, и културолошки, па и етнолошки феномен”, указујући на то да је псовка само део ширег појма - опсцених речи (Ibid., 178). Попут Д. Шипке, и она истиче да „садржај опсцених речи и израза подразумева првенствено сексуалне радње и органе, [као] и екскреционе радње и садржаје" (ВицАновит 2017: 178). Као функције опсцених речи ауторка наводи да се њима исказују емоције, да се њима ослобађа напетост, да се прецизније преносе жељене поруке (Ibid., 187). Нема сумње да све оно што припада пољу опсцене лексике није аутоматски и колоквијално/жаргонско, ${ }^{16}$ али су овде издвојене оне лексеме које то свакако јесу.

a) Опсцени садржај је именован неутралним лексемама, нпр.:

Бола ме је сисама док ме љубила. Пайка ми се моменйално укруиила. (49)

У непристојну тј. опсцену лексику спадају називи за делове тела који су по правилу покривени/скривени (од погледа других људи). Такви изрази могу настати метафоризацијом (примарно) неопсецних речи односно модификацијом постојећих речи. Тако нпр. у роману $O g 13$ go 18 гл. јунак за мушки полни орган користи реч $\bar{u} a \bar{u} \kappa a$.

б) У погледу бројности доминирају непристојне речи које су употребљене тако да не денотирају конкретну опсцену (сексуалну/екскрециону) активност, него се реализују у оквиру псовачког дискурса:

${ }^{16}$ В. рад Ј. Марковић (2017). 
Е ДО КУРЦА! - йродрао се Ћойави. (11) Не озбиљно, који ће тии кураи решейке на йрећем сирайуу? (14) Не сери... (14) Ко је јебе! (14) Koj ће кураи у Аранђеловиу? (15) Не сери, био сам убеђен. (16) У јеботе, ал си клинац. (16) Шӣа се яркаш, зезамо се мало. (16) E cag баш нећу, ко

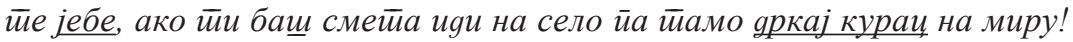

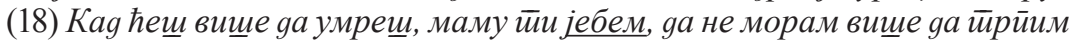
ова иивоја срања! Бежи бре смраяе муйави, іони се у йри куриа, марш у ииззуу майерину. (22) Ма неее, кој ӥи је кураи. (22) Сисаи ми кару, Муйави! Који си тии болия, коюино! Пуши кураи! Јеqи іовна кевина, Муйави!

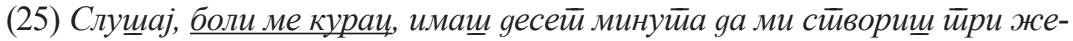

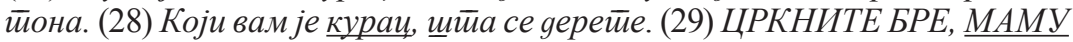
BАМ ЈЕБЕМ, УГУШИТЕ СЕ У КЕСИ, ПИЗДА ЛИ ВАМ МАТЕРИНА! (30)

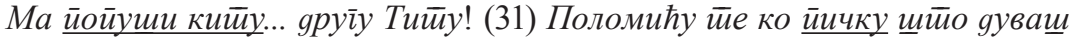
лейак, мајмуне! (32) Ди си наркомане, немам лейак, али можеш мало gа ми йоqуваш кураu! (34) ПИЧКЕТИНО СМРДЉИВА (...) (34) Пустиийе ме бре вище, кој вам је кураи, шита хоћетие о ммене? (34) (...) Маму йи јебем... (38) ДЕ СТЕ ЗЕМУНЦИ БРЕ, ЈЕБО ВАС КУРАЦ! (38) Ћуйи ке...кењај!

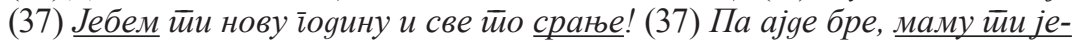
бем, иитиа је бре ово нищйа не раяи, ручка је жив курац. () Ко йа јебе,

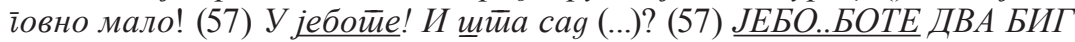
МЕКА! (60) Црни, је...јебеш ми ма..ма..йер (...). (61) То је неки Рус ваљgа, јебем ли іа... (66) Јеgи їовна бре менйолу, їgе се йомерио! (67) Гойово,

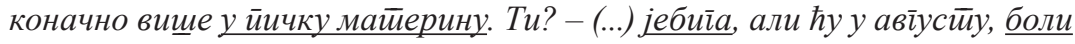
ме кураи. (72) Јебиі̆а, исиоолағали ми очене. (73) Па gобро, боли йебе кураи (...). (73) Гgе си бре човече, ияи у кураи! (91) Јебем вам мајку свима, мајку вам јебем устиашку... маму вам јебем (...) јао шйи стие ми ураяили, иичке јеgне, мајку ли вам јебем да вам јебем... (107) E, немој gа ми кењаш (...). (129) Не сери вище, шиимаш се йамо йола gана (...). (130) Не сери байице, неїо шитиа ћемо ми? (131) Немој gа ми сереш! (141) Е, немој јоми и ий gа ме дркаш, довољно су ме сморили на іајби. (142)

в) врло често је опсцена лексика употребљена како би се денотирала некаква неопсцена радња или понашање и расположење појединца:

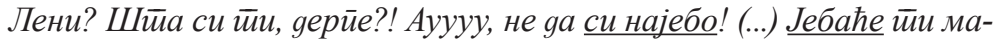
йер. (57) (...) али јеgном ме усрало (...). (61) Баш жещће срање у Сйлийу, $a$ ? (65) Наравно, ниједном је нисам дочекао, й сам ищао кући сав сјебан. (68) Прво ми је ишла на кураи с њеним беоіраяским ирренемаїањем. (69) А ја сам се сјебо (...). (72) Ја вище волим ХаЦе бенgове који найињу мейалу, који иии јебу кеву йосле иррвоі рифа. (90) Увек се нешито усерем каg сам у йрилици. Невиђена је риба! (96) Нисуми йуно кењали. (...) Кайирам gа сам суйра најебо, кая сииварно скайирају да сам избачен. (119)

г) опсцена лексика употребљена је и да денотира сексуалне и екскреционе радње и (полне) органе:

Јеси карао некаg? (...) Јеси се жвалавио са рибом? (12) Наркомани, карају се у буљу за gроїу (32). Каg би се скочкала, каg би мало наяркала 
сисе, йоказала нойе, била би суйер за карање. (33) Јел знаши који је нови израз за qркање китее? (36) Дрко је кураи на часу франиускоі. Не се...сери. (36) Сео у заяюу клуйу и дрко. Франиускиња је ойасна йичка, йлавущиа. И ја сам іа реgовно дрко на юу. (36) (...) о овалио би је о куриа! (36) Сео је у йрву клуйу, стиавио ойлеgало на йайику и йлеgао јој у йичку. (36)

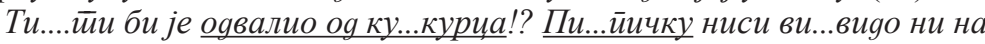

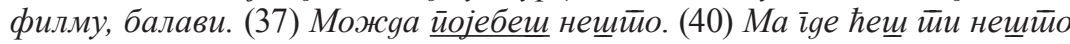

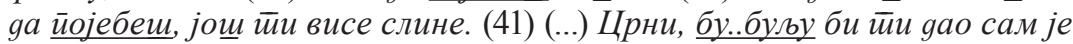

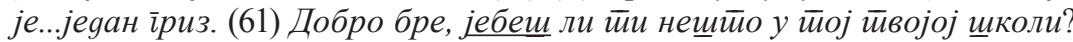
(68) И јел си је карао? (...) Вайала ме за кийу, а ја сам јој ірабио сисе. (69) И боље шито је ниси карао. Јебање йоквари оянос са рибом, ако је волищ. (...) После карања, йо вище није било т̄о. (69) Ја Цану оgма јебем у буљу. Прво је нешито кенкала, а сая сваки йуй каg се карамо йаgа чмар. (94) - Јел тии йуши, ова моја сиса ко блесава. (...) Нейо, јел јој йушиш gуйе? (94) Јел ироваљујет̄е gа је највећи беgак каg не искењаш одма све, неі̆о исереш јеgан део, йа оняа чекаш на щољи, найињещи се ко коњ gа изађу неки брабоњичи... (99) Бићу заяовољнији кая ми іа йойушищ! (122) - Оћещ gа ме јебеш, оћеш gа ме јебеш! (122) (...) ииий извлачи лајн, а gве невиђене ииччке му лижу кару... (131) Па щйй, йа и ја gа сам неки кримос само бих блејао йо хойелима, карао курве, раяио кокс (...). (135) Оиеей нисам моїао яа шорам. (151)

д) опсцена лексика употребљена је и за квалификовање и интензификовање:

УЂемо ми у яискойеку, а музика срање. (84) То су срање беняови. (90) - Па како је било? - Било је gо јаја. (92) Ма вияећещ, биће тии gо јаја (...). (138) Умело је gа буgе зајебано gо јаја. (142)

Показује се да су најбројније колоквијално-жаргонска лексичке јединце у роману оне опсценог карактера. Избором овакве лексике предочава се грубост/огрубелост тинејџера у понашању и интеракцији, као и идиомска униформност. Ово прво је видљиво у оквиру примера (б) скупине, који илуструју псовачки дискурс, где се најчешће јављају речи и синтагме попут

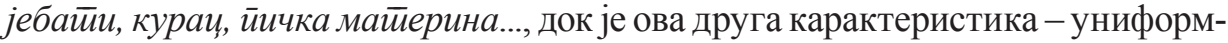
ност - видљива у групи примера (в), где би се могле идентификовати различите радње, али су сведене најчешће на два глагола: јеба $\bar{u} u$ и срайи, а од овакве језичке слике не одударају много примери ни у скупини (г), па и (д), где се за квалификовање и интензификовање варирају реч и конструкција срање и gо јаjа.

3. ЗАКљУчАК. Омладински социолект, у стилизованом наративном остварењу, доминира у комуникацији међу ликовима (омладином) у роману. Писац помоћу њега исповеда одређено осећање света актуално за доба приповести, што никако не значи да је данас дезактуализовано. Млади употребљавају свој супкултурни, неформални идиом како би се разликовали од других и 
на тај начин омеђили сопствено окружење и приступ социјалној групи, те ограничили разумевање садржаја порука које размењују.

На основу анализираних примера у роману $O g 13$ go 18 уочава се да млади протагонисти у овом прозном делу (почињу да) користе колоквијално-жаргонску лексику како би били прихваћени међу својим вршњацима, будући да увек постоји страх од подсмеха (или одбацивања са стране) осталих чланова генерацијске групе (уколико изостане приклањање већини). Њихов начин комуникације је прожет, тачније „натопљен” некњижевном (разговорно-жаргонском) лексиком - управо ради опонирања и разликовања од говорног обрасца одраслих, док тај формални (стандардни) облик комуникације и бирана лексика постоје само у траговима у роману, ограничени на неколико говорних ситуација, тј. наративних епизода. Главни јунак овог романа је имао своје идоле у вршњацима (и онима нешто старијима), па желећи да постане члан њихове групе покушава да им буде што сличнији у начину изражавања (дакако и у понашању, те отуд почиње користити, дружећи се са њима, различите психоактивне супстанце), што доводи до тога да у језик уноси бројне колоквијализме и жаргонизме, јер да би се неко идентификовао као члан једне групе потребно је да буде „социолингвистички акултурализован”, тј. да се у конверзацији користи одговарајућим маркерским речима и изразима. Најизразитије се употреба такве лексике примећује у пољу везаном за номинацију особа (посебно негативно конотирана/вулгарна кад је реч о женама) и у случају тематског поља везаног за дрогу. Напослетку, иако не само тематски него и функционално издвојена, јавља се и веома бројна опсцена лексика. Како је другде истакнуто (СтЕпАнов 2019), Рашић, одн. његови јунаци сагледавају ствари на витгенштајнов(ски) начин: тако границе „нашег”, тј. омладинског (колоквијално-жаргонског) језика бивају уједно и границама (нашег) света. Тај колоквијално-жаргонски вернакулар постаје конструктиван за текстуални свет у којем су изразито фокусирана значења и ставови које заступају тинејџери: ништа ван тог језика и света није толико важно, тј. оно што је с оне стране тог социолекта - језик родитеља/школе/ одраслих - за јунака романа (и његове вршњаке) бива тек као фон спрам којег се рађа и којем опонира маргинализована омладина живећи у свом свету и са својим говором.

\section{ИЗВОР И ЦИТИРАНА ЛИТЕРАТУРА}

ВицАновић, Марина. Функције опсцених речи и израза у српској култури. Ойсиена лексика у срйском језику. Марковић, Ј. (прир.). Ниш, Филозофски факултет, 2017, 173-206.

Драгићевић, Рајна. Срӣска лексика у йрощлостии и gанас. Нови Сад: Матица српска, 2018. 
МАрковић, Јордана. Статус опсцене лексике у жаргону. Ойсиена лексика у срйском језику. Марковић, Ј. (прир.). Ниш, Филозофски факултет, 2017, 61-74.

РАшић, Александар. Og 13 gо 18: лекіиира за основну щкколу. Београд: ЛОМ, 2016.

Ристић, Стана. Раслојеносй лексике срйской језика и лексичка норма. Београд: Институт за српски језик САНУ, 2006.

Тошовић, Бранко. Стилизација. Кюижевна истиорија XII/45 (1979): 91-127.

Тошовић, Бранко. Функиионални стиилови. Београд: Београдска књига, 2002.

ШипкА, Данко. Ойсиене речи у срӣском језику. Нови Сад: Прометеј, 1999.

*

BoXer, Diana. Applying Sociolinguistics: Domains of Face-to-Face Interaction. Amsterdam: John Benjamins, 2002.

Bugarski, Ranko. Žargon. Beograd: Biblioteka XX vek, 2006.

EMmison, Michael. On the analyzability of conversational fabrication: A conceptual inquiry and single case example. Australian Review of Applied Linguistics 16 (1993): 83-108.

Flaker, Aleksandar. Proza u trapericama. Zagreb: Liber, 1983.

Gaitet, Pascale. Political Stylistics: Popular Language as Literary Artifact. London: Routledge, 1992.

Katnić BaKaršıć, Marina. Stilistika. Sarajevo: Ljiljan, 2007.

Klikovac, Duška. Jezik i moć. Beograd: XX vek, 2008.

Kolanović, Maša. Dosezi i granice simboličkog otpora: „Proza u trapericama” u kontekstu jugoslavenskog socijalizma. Poznańskie Studia Slawistyczne 6 (2014): 129-143.

Llamas, Carmen. The Routledge Companion to Sociolinguistics. Age. Llamas, C.; Mullany, L; Stockwell, P. (eds.) New York - London: Routledge. 2007: 69-76.

MarčEtić, Aleksandra. Figure pripovedanja. Beograd: Narodna knjiga, 2004.

Radovanović, Milorad. Sociolingvistika. Sremski Karlovci - Novi Sad: IKZS, 2003.

Savić, Svenka, Vesna Polovina. Razgovorni srpskohrvatski jezik. Novi Sad: Filozofski fakultet, 1989.

Stepanov, Strahinja. Razgovorna stilizacija u romanu Aleksandra Rašića Od 13 do 18. Anzeiger für slavische Philologie XLVI (2019): 219-233.

Schmid, Wolf. Narratology : An Introduction. Berlin - New York: Walter de Gruyter GmbH \& Co, 2010.

SCHEGLOFF, Emanuel. Goffman and the analysis of conversation. Erving Goffman: Exploring the Interaction Order. Drew, P.; Wotton, A. (eds.). Oxford: Polity Press, 1988, 89-135. 
Strahinja R. Stepanov

\section{COLLOQUIAL AND SLANG WORDS IN ALEKSANDAR RAŠIĆ'S NOVEL FROM 13 TO 18: READING FOR SCHOOL}

\section{Summary}

The object of the current investigation in this paper are colloquial and slang words in Aleksandar Rašićs novel From 13 To 18: Reading for School. Given the novel's subject matter - growing up of the main protagonist (from his $13^{\text {th }}$ birthday till he is 18 ) during turbulent and violent years of the country's breakup (late 80s and early 90s of 20th century) - the author deploys youth (substandard) vernacular when representing discourse between young, teenage protagonists. Jargonization, realized not only in dialogical but also in non-dialogical (diegetic) sequences of the novel, affects solely youth characters. This paper is organized in three parts: first part will briefly outline the narrative characteristics of the novel, second part will present the extracted examples of colloquial and slang lexemes, and their classification and analysis based on the meaning and derivation, while third part will provide conclusions regarding the analyzed vocabulary.

Универзитет у Новом Саду

Филозофски факултет

Одсек за српски језик и лингвистику

Др Зорана Ђинђића 2, 21000 Нови Сад

strahinja.stepanov@ff.uns.ac.rs 